ISSN 1392-3196 / e-ISSN 2335-8947

Zemdirbyste-Agriculture, vol. 106, No. 1 (2019), p. 37-44

DOI 10.13080/z-a.2019.106.005

\title{
The incidence and severity of take-all in winter wheat and Gaeumannomyces graminis soil inoculum levels in Lithuania
}

\author{
Jūratė RAMANAUSKIENĖ, Zenonas DABKEVIČIUS, Kęstutis TAMOŠIŪNAS, \\ Eglè PETRAITIENE
}

Institute of Agriculture, Lithuanian Research Centre for Agriculture and Forestry

Instituto 1, Akademija, Kèdainiai distr., Lithuania

E-mail: jurate.ramanauskiene@lammc.lt

\begin{abstract}
In recent years, because of the constantly changing farming systems and under a limited choice of alternative crops, many farmers have been growing the same crops in the same fields for two or more consecutive years. This practice has resulted in increasing incidence and severity of take-all in winter wheat (Triticum aestivum L.) crops. The aim of this study was to evaluate the incidence and severity of take-all in winter wheat and estimate the level of Gaeumannomyces graminis var. tritici $(G g t)$ and G. graminis var. avenae $(G g a)$ inoculum in the soil in three agro-ecological zones (Western, Middle Lowland and Eastern) of Lithuania. During the 2013-2014 period, takeall incidence in winter wheat varied from $2.0 \%$ to $92.0 \%$ in 81 fields inspected. The highest take-all incidence and take-all index were identified in the Middle Lowland zone, while the lowest in the Western zone. The inoculum level of Ggt/Gga in the soil was estimated using the bait method by assessing DNA amounts of pathogens in the roots of wheat plants, grown in the soil samples collected in different agro-ecological zones of Lithuania. The amounts of Ggt/Gga DNA varied considerably among the sites. Averaged data showed the lowest take-all inoculum level in Eastern zone and the highest in Middle Lowland. The highest amount of Ggt/Gga DNA was established in the samples collected in Pakruojis and Panevėžys districts. In three samples from Raseiniai, Šiauliai and Alytus districts the quantity of fungal DNA was very small $0.188-0.640 \mathrm{pg}$ of fungal DNA $\mu \mathrm{g}^{-1}$ of plant DNA, and in five samples from Šilutè, Tauragè, Telšiai, Kėdainiai and Panevėžys districts no fungal DNA was detected. In this study, the use of different management and different environmental conditions, also unpredictability of the disease (ability to spread in patches), probably were the main reasons, which had significant impact on the marked variation of take-all incidence and severity in winter wheat crops in Lithuania.
\end{abstract}

Key words: fungal inoculum, quantification, take-all index, Triticum aestivum.

\section{Introduction}

Take-all is one of the most important root diseases of winter wheat (Triticum aestivum L.) in all cropping areas around the world. The disease is of a particular relevance in the countries, including Lithuania, where the wheat cultivation area has increased and monocropping (crops grown in the same field for two or more consecutive years) is a common practice. Take-all can cause plant death or premature maturation resulting in the appearance of white-heads, which significantly reduce grain yield and quality (Gutteridge et al., 2003). Yield losses as high as $50-60 \%$ can be incurred due to the severe epidemics (Shoeny et al., 2001; McMillan et al., 2011). The main causal agent of this disease, soilborne fungus Gaeumannomyces graminis var. tritici (Ggt), is the most economically important pathogen (Hornby et al., 1998). Based on pathogenicity, G. graminis species includes three other varieties: $G$. graminis var. avenae
(Gga), G. graminis var. graminis (Ggg) and G. graminis var. maydis $(\mathrm{Ggm})$. The two last mentioned varieties ( $G g g$ and $G g m$ ) are more closely associated with takeall in rice and maize, respectively, and are weakly dangerous on wheat. Gga is a causal agent of take-all in oats, but may affect wheat too (Walker, 1981; Freeman, Ward, 2004).

G. graminis var. tritici inoculum can persist for long periods saprophytically in soil on crop debris (Curtin et al., 2008). Two stages of infection are described: primary infection occurs from infected residues on seminal roots, and secondary infection results by mycelial contact from infected roots to susceptible roots (Bailey, Gilligan, 1999). For this reason, the disease is most commonly distributed in circular patches. Take-all is manifested as dark brown to black rotten lesions on the roots (Bockus, Tisserat, 2000). The early infection

Please use the following format when citing the article:

Ramanauskienè J., Dabkevičius Z., Tamošiūnas K., Petraitienè E. 2019. The incidence and severity of take-all in winter wheat and Gaeumannomyces graminis soil inoculum levels in Lithuania. Zemdirbyste-Agriculture, 106 (1):37-44. DOI 10.13080/z-a.2019.106.005 
disrupts the water and nutrient flow to the plant stem, which leads to premature maturation. Because of rotted roots, wheat plants with severe infection are easily pulled from the soil (Cook, 2003).

Take-all development and severity depend on the amount of initial inoculum of $G$. graminis var. tritici in the soil and environmental conditions. Primarily, this is determined by the field history and by the severity of the disease in the previous crop (Hornby et al., 1998). Severity of take-all is usually low in the first wheat after non-host crops and can be high in the second crops (Werker, Gilligan, 1990; Cromey et al., 2006; Jenkyn et al., 2014). However, the prolonged cereal cultivation in the same field shows partial efficiency in limiting takeall risk; the research shows that usually after the fourth year, in later seasons a take-all decline occurs (Weller et al., 2002; Cook, 2003; 2007; Bailey et al., 2009). Soil type and moisture are very important factors for the spread of take-all. The disease is likely to be more active in the soils with high light silt content, especially in wet seasons (Hornby et al., 1998; Cook, 2003). Control of take-all is complicated, because resistant wheat cultivars are not available and the choice of crop protection products is very limited (Weller et al., 2002; Gutteridge et al., 2003; Kwak, Weller, 2013). Depending on the soil and climate of the location, crop rotation with a break of non-host plants for one or two years is a most effective method in controlling take-all (Cook, 2003; Ramanauskienè et al., 2018).
The aim of this study was to evaluate the incidence and severity of take-all in winter wheat crops and estimate the combined level of $G$. graminis var. tritici and G. graminis var. avenae inoculum in the soil in different agro-ecological zones of Lithuania.

\section{Materials and methods}

Field sites and sampling. In 2013 and 2014, winter wheat (Triticum aestivum L.) plant and soil samples were collected from the commercial fields in three agro-ecological zones of Lithuania. The fields were chosen randomly, and during two years a total of 81 samples from 29 districts (23 samples from Western, 47 samples from Middle Lowland and 11 samples from Eastern zones) were taken. The plant sampling was done at milk-ripening stage. Growth stages were defined according to the $\mathrm{BBCH}$ scale (Witzenberger et al., 1989). Approximately 20 plants from 5 places (in total 100 stems) were dug randomly from a field. The plant samples were analysed visually and take-all incidence and severity were determined (Fig. 1). From five spots of each field, $5.5 \mathrm{~cm}$ diameter $\times 10 \mathrm{~cm}$ deep soil cores were randomly collected for estimation of inoculum level of Gaeumannomyces graminis var. tritici and G. graminis var. avenae.

Disease assessment. The roots of 100 plants collected from the field were analysed for take-all severity, assessed as the percentage of affected root area.

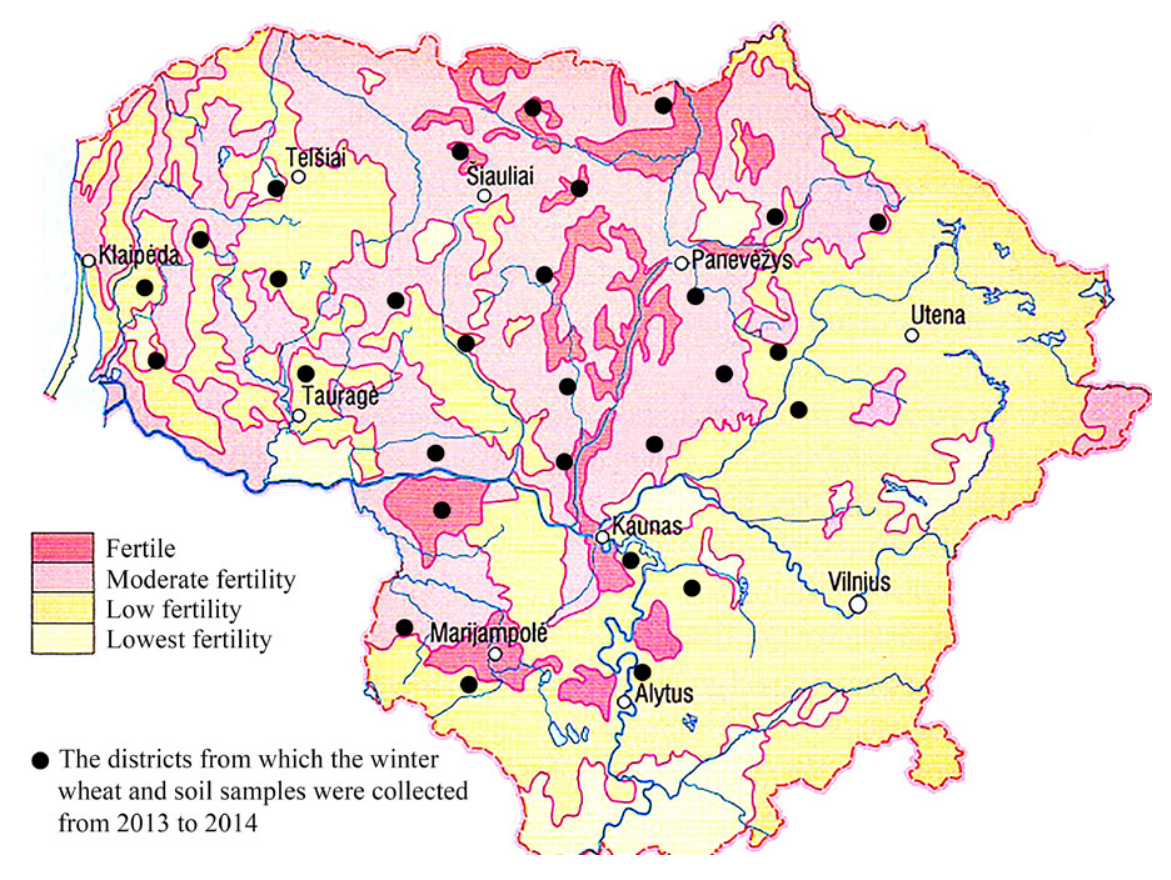

Figure 1. Sampling sites and fertility of Lithuanian soils

Assessments were done according to Bithell et al. (2012) using the 0 to 4 scale, where 0 - no disease, $1-1-10 \%$ of root system affected, $2-11-30 \%$ of root system affected, $3-31-60 \%$ of root system affected, $4-61-100 \%$ of root system affected. The number of plants in each sample was used to calculate the take-all index (TAI):

$\mathrm{TAI}=(0 \mathrm{~N} 1+10 \mathrm{~N} 2+30 \mathrm{~N} 3+60 \mathrm{~N} 4+100 \mathrm{~N} 5) / \mathrm{T}$,

where $\mathrm{N}$ is the number of plants in each of the five infection categories, $\mathrm{T}$ - the total number of assessed plants. The incidence of take-all was calculated as the percentage of infected plants in each sample.
Inoculum in the soil. The level of inoculum of take-all in the soil was estimated using the bait method (Gutteridge, Hornby, 2003). Five plastic cups, $7.5 \mathrm{~cm}$ in diameter and $11 \mathrm{~cm}$ in height, containing drainage holes were filled with soil samples from each field. Prior to that, $1 \mathrm{~cm}$ of coarse sand was placed on the bottom of each cup. Breeding varieties for resistance to takeall is the most promising way to protect cereals, but no effective resistance has been achieved yet (Gutteridge et al., 2003; Yang et al., 2011), therefore we arbitrarily chose a Lithuanian winter wheat cultivar 'Kovas DS'. 
Ten non-treated grains were placed on the soil surface and covered with clay beads. The cups were watered and placed in a controlled growth chamber at $12^{\circ} \mathrm{C}$ in a $16 / 8$ day/night regime. The cups were watered twice a week. After six weeks, plants were pulled from the soil. The roots were washed and homogenized in liquid nitrogen. Homogenized samples were stored in 2-ml micro centrifuge tubes at $-20^{\circ} \mathrm{C}$ for DNA extraction.

$D N A$ extraction and real-time polymerase chain reaction (RT-PCR). G. graminis var. tritici and $G$. graminis var. avenae DNA extraction from winter wheat roots was carried out on composite samples. DNA was extracted using a commercial genomic DNA purification kit (Thermo Fisher Scientific Baltics, Lithuania) according to the manufacturer's instructions. The DNA extraction was done in two replicates from one homogenized sample.
Real-time PCR was carried out in $20 \mu \mathrm{l}$ of reaction mixture comprising $10 \mu \mathrm{l}$ Maxima $^{\mathrm{TM}}$ SYBR Green qPCR Master Mix (Thermo Fisher Scientific Baltics), $2.5 \mu$ l tested DNA, $6.9 \mu 1$ nuclease-free water and $0.3 \mu \mathrm{l}$ of each forward and reverse primer. DNA of $G$. graminis var. tritici plus avenae (tritici/avenae) was quantified using specific combined primers Ggtritici/ avenaeF and Ggtritici/avenaeR (Bithell et al., 2012). Primers Hor 1F/Hor2R were used for the detection of plant DNA and for normalisation of the reactions (Table 1).

A five-fold dilution series with $G$. graminis var. avenae ( $G g a)$ DNA isolated from pure cultures obtained from the VTT Technical Research Centre of Finland Culture Collection and with plant DNA extracted from winter wheat were used for individual standard curves. The reactions were calculated as pg of fungal DNA per $\mu \mathrm{g}$ of plant DNA (Nicolaisen et al., 2009). PCR was

Table 1. Specific primers and their sequences

\begin{tabular}{lll}
\hline \multicolumn{1}{c}{ Target } & \multicolumn{1}{c}{ Primer } & \multicolumn{1}{c}{ Sequence (5'-3') } \\
\hline G. graminis var. tritici/avenae & Ggtritici/avenaeF & AACTCCAACCCCTGTGACCA \\
& Ggtritici/avenaeR & CGCTGCGTTCTTCATCGATGCC \\
Plant EF1 $\alpha$ & Hor1F & TCTCTGGGTTTGAGGGTGAC \\
& Hor2R & GGCCCTTGTACCAGTCAAGGT \\
\hline
\end{tabular}

performed in three replications with a 7900HT Fast Sequence Detection System (Applied Biosystems, USA). Procedure regime was modified by Liu et al. (2013) and following cycling regime $95^{\circ} \mathrm{C}$ for $10 \mathrm{~min}\left(95^{\circ} \mathrm{C}\right.$ for $15 \mathrm{~s}$ and $60^{\circ} \mathrm{C}$ for $35 \mathrm{~s}$ ) were used.

Statistical analysis. Data of take-all incidence and take-all index were analysed using the software $S A S$, version 9.4 (SAS Institute Inc., USA) and presented as mean and standard errors of the means. PROC CORR procedure was used for Person's correlation test between disease infection indicators (take-all incidence and takeall index), cultivation areas and amounts of fungal DNA.

\section{Results}

The incidence and severity of take-all in Lithuania. The fields were chosen arbitrarily and the results of the present study represent the overall takeall occurrence in Lithuania. Over the 2013-2014 period, the presence of take-all was identified in $95.0 \%$ of the total 81 winter wheat fields inspected. Depending on the location, environmental and cultivation conditions the disease incidence in winter wheat fields varied from $2.0 \%$ to $92.0 \%$ (Table 2). Of all the tested fields, in four of them symptoms of take-all were not identified.

Table 2. The disease incidence and take-all index (TAI) (\%) in winter wheat, 2013 and 2014

\begin{tabular}{|c|c|c|c|c|}
\hline District & Incidence & TAI & Incidence & TAI \\
\hline 1 & 2 & 3 & 4 & 5 \\
\hline \multicolumn{5}{|c|}{ Western zone } \\
\hline Kelmè & 10.0 & 1.60 & na & na \\
\hline Klaipėda & 38.0 & 7.40 & 12.0 & 1.20 \\
\hline Plungė & 34.0 & 5.00 & 4.0 & 0.40 \\
\hline Raseiniai & 28.0 & 9.40 & 2.0 & 0.20 \\
\hline Šilalè & 68.0 & 21.60 & na & na \\
\hline Šilutė & 0 & 0 & 4.0 & 0.40 \\
\hline Tauragè & 4.0 & 0.40 & 14.0 & 2.40 \\
\hline Telšiai & 12.0 & 1.20 & 12.0 & 1.20 \\
\hline Mean & $24.3 \pm 9.41$ & $5.83 \pm 3.41$ & $8.0 \pm 2.13$ & $0.90 \pm 0.34$ \\
\hline \multicolumn{5}{|c|}{ Middle Lowland zone } \\
\hline Jonava & 44.0 & 4.40 & 6.0 & 0.60 \\
\hline Joniškis & na & na & 36.0 & 14.40 \\
\hline Jurbarkas & na & na & 8.0 & 0.80 \\
\hline Kaišiadorys & 82.0 & 24.80 & na & na \\
\hline Kaunas & na & na & 0 & 0 \\
\hline Kèdainiai & 38.0 & 11.80 & 38.0 & 13.60 \\
\hline Kupiškis & na & na & 0 & 0 \\
\hline Marijampolè & 60.0 & 15.60 & 24.0 & 7.00 \\
\hline Pakruojis & 6.0 & 0.60 & 6.0 & 0.60 \\
\hline Panevéžys & 64.0 & 17.20 & 80.0 & 14.00 \\
\hline Pasvalys & 46.0 & 15.40 & 92.0 & 20.40 \\
\hline Prienai & 70.7 & 8.67 & 20.0 & 2.00 \\
\hline Radviliškis & 12.0 & 1.20 & 32.0 & 5.80 \\
\hline
\end{tabular}


Table 2 continued

\begin{tabular}{|c|c|c|c|c|}
\hline 1 & 2 & 3 & 4 & 5 \\
\hline Šakiai & 34.0 & 4.60 & 12.0 & 1.20 \\
\hline Šiauliai & 4.0 & 0.40 & 24.0 & 2.40 \\
\hline Vilkaviškis & 100.0 & 29.20 & 0 & 0 \\
\hline Mean & $46.7 \pm 8.73$ & $11.16 \pm 2.76$ & $25.2 \pm 9.68$ & $5.49 \pm 4.57$ \\
\hline \multicolumn{5}{|c|}{ Eastern zone } \\
\hline Alytus & 42.0 & 7.40 & na & na \\
\hline Anykščiai & na & na & 8.0 & 0.80 \\
\hline Rokiškis & na & na & 12.0 & 1.20 \\
\hline Ukmergė & 58.0 & 11.80 & 26.0 & 7.60 \\
\hline Širvintos & na & na & 10.0 & 1.00 \\
\hline Mean & $50.0 \pm 8.00$ & $9.60 \pm 2.20$ & $14.0 \pm 4.08$ & $2.65 \pm 1.65$ \\
\hline Mean in Lithuania & $40.3 \pm 9.41$ & $8.96 \pm 3.41$ & $15.7 \pm 3.43$ & $3.01 \pm 1.52$ \\
\hline Min & 4.0 & 0.40 & 2.0 & 0.20 \\
\hline Max & 82.0 & 29.20 & 92.0 & 20.40 \\
\hline
\end{tabular}

Min - the lowest, Max - the highest take-all incidence and TAI; \pm - standard error of the mean, na - not assessed

A comparison of data from different agroecological zones of Lithuania indicated that the highest take-all incidence and take-all index were in the Middle Lowland zone and the lowest in the Western zone. The highest $(29.20 \%)$ TAI was established in the Middle Lowland zone, while the lowest $(0.20 \%)$ TAI was determined in the Western zone.

Take-all inoculum level in the soil. Inoculum level of $G$. graminis var. tritici plus $G$. graminis var. avenae $(G g t / G g a)$ in the soil was estimated using the bait method by assessing DNA amounts of pathogens in plant roots, grown in the soil samples from different agroecological zones of Lithuania. The lowest concentrations of pathogens were established in Eastern zone, while the highest concentrations were determined in Middle Lowland zone (Table 3).

Table 3. The amounts of Gaeumannomyces graminis var. tritici plus avenae (Ggt/Gga) (pg of fungal DNA per $\mu \mathrm{g}$ of plant DNA) in the soil described by mean values and 95\% confidence interval, 2013 and 2014 (bait method)

\begin{tabular}{|c|c|c|c|}
\hline \multirow[b]{2}{*}{ District } & \multicolumn{3}{|c|}{$G g t / G g a$ DNA (pg of fungal DNA $\mu \mathrm{g}^{-1}$ of plant DNA) } \\
\hline & 2013 & 2014 & $\begin{array}{l}\text { total amount of } \\
2013 \text { and } 2014\end{array}$ \\
\hline 1 & 2 & 3 & 4 \\
\hline \multicolumn{4}{|c|}{ Eastern zone } \\
\hline Alytus & 1794.35 & 0.642 & 1794.99 \\
\hline Anykščiai & na & 442.67 & 442.67 \\
\hline Rokiškis & na & 9.66 & 9.66 \\
\hline Ukmergè & 4476.07 & 1838.21 & 6314.28 \\
\hline Širvintos & na & 3767.33 & 3767.33 \\
\hline Mean & $3135.21 \pm 2626.4$ & $1211.70 \pm 1414.0$ & $2465.76 \pm 2278.8$ \\
\hline Amount & 6270.42 & 6058.51 & 12328.93 \\
\hline \multicolumn{4}{|c|}{ Middle Lowland zone } \\
\hline Jonava & 1084.94 & 54.68 & 1139.62 \\
\hline Joniškis & na & 157.33 & 157.33 \\
\hline Jurbarkas & na & 223.92 & 223.92 \\
\hline Kaišiadorys & 1857.41 & na & 1857.41 \\
\hline Kaunas & 850.25 & 4519.02 & 5369.27 \\
\hline Kèdainiai & 820.94 & 0 & 820.94 \\
\hline Kupiškis & na & 252.35 & 252.35 \\
\hline Marijampolè & 1734.86 & 517.32 & 2252.18 \\
\hline Pakruojis & 9117.16 & 8.68 & 9125.84 \\
\hline Panevėžys & 5158.63 & 0 & 5158.63 \\
\hline Pasvalys & 2703.21 & 1221.82 & 3925.04 \\
\hline Prienai & 122.09 & 137.82 & 259.90 \\
\hline Radviliškis & 67.36 & 593.93 & 661.29 \\
\hline Šakiai & 421.70 & 179.04 & 600.74 \\
\hline Šiauliai & 694.21 & 0.19 & 694.40 \\
\hline Vilkaviškis & 37.34 & 1496.32 & 1533.66 \\
\hline Mean & $1897.70 \pm 1402.4$ & $624.16 \pm 1106.2$ & $2127.03 \pm 1239.0$ \\
\hline Amount & 24670.11 & 9362.41 & 34032.52 \\
\hline \multicolumn{4}{|c|}{ Western zone } \\
\hline Kelmé & 587.23 & na & 587.23 \\
\hline Klaipèda & 2095.06 & 120.61 & 2215.67 \\
\hline Plungè & 4914.32 & 721.16 & 5635.47 \\
\hline Raseiniai & 1335.03 & 0.57 & 1335.60 \\
\hline Šilalè & 1731.88 & na & 1731.88 \\
\hline
\end{tabular}


Table 3 continued

\begin{tabular}{|c|c|c|c|}
\hline 1 & 2 & 3 & 4 \\
\hline Šilutė & 735.77 & 0 & 735.77 \\
\hline Tauragè & 507.26 & 0 & 507.26 \\
\hline Telšiai & 14179.09 & 0 & 14179.09 \\
\hline Mean & $3260.71 \pm 3211.0$ & $140.39 \pm 308.7$ & $3366.00 \pm 3238.0$ \\
\hline Amount & 26085.64 & 842.34 & 26927.98 \\
\hline Mean in Lithuania & $2479.40 \pm 1685.0$ & $625.51 \pm 169.1$ & $2527.22 \pm 1159.0$ \\
\hline Amount in Lithuania & 57026.17 & 14723.77 & 73289.42 \\
\hline Min & 37.34 & 0.19 & 9.66 \\
\hline Max & 9117.16 & 4519.02 & 14179.09 \\
\hline
\end{tabular}

Min - the lowest, Max - the highest amount of Ggt/Gga DNA; $\pm-95 \%$ confidence interval; na - not assessed

Quantification of the biomass of Ggt/Gga DNA showed that for each agro-ecological zone there is a large variation between samples, reflected by the $95 \%$ confidence interval. Of the total 81 samples investigated the highest amounts of Ggt/Gga DNA was established in the samples collected in Pakruojis and Panevèžys districts, while the lowest in Rokiškis district. In three samples from Raseiniai, Siauliai and Alytus districts the quantity of fungal DNA was very small $-0.188-0.642$ pg of fungal DNA $\mu \mathrm{g}^{-1}$ of plant DNA, and in five samples from Šilutè, Tauragè, Telšiai, Kèdainiai and Panevéžys districts no fungal DNA was detected.

The data averaged over two years showed the highest incidence and severity of the disease in Middle Lowland zone; however, the highest amounts of $G g t / G g a$ DNA were established in the samples from Western zone (Fig. 2).

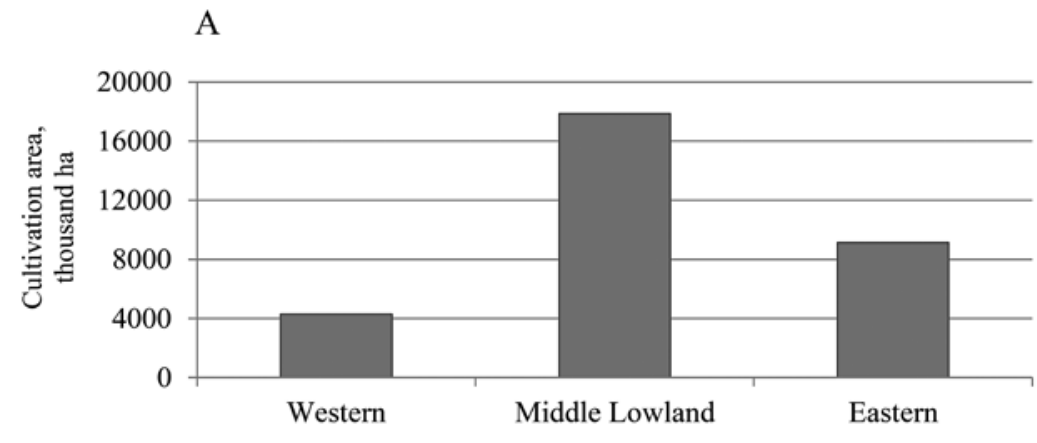

B

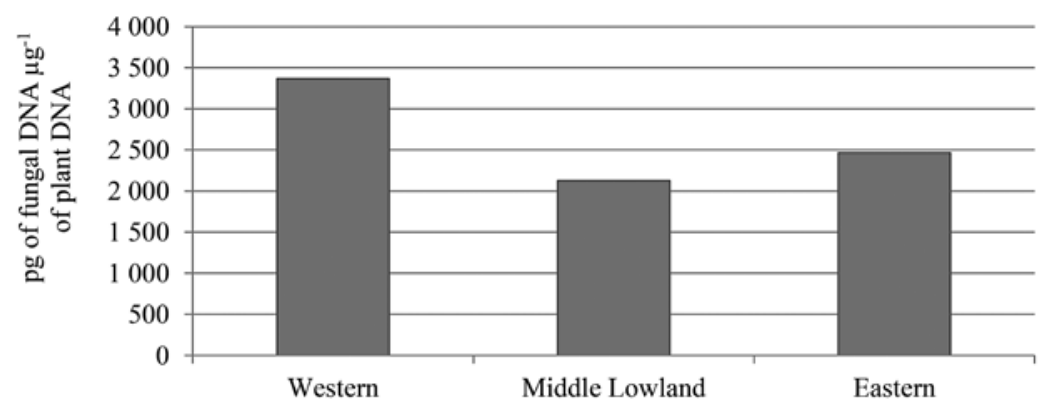

Figure 2. Average of winter wheat cultivation area (A) and amounts of Gaeumannomyces graminis var. tritici/avenae DNA (B) in different agroecological zones of Lithuania, 2013 and 2014

Correlation analysis. Pearson's correlation test showed moderately significant relationships between grown areas of winter wheat in Lithuania and take-all inoculum level in the soil (measured by estimating the amounts of G. graminis var. tritici/avenae DNA in the roots of winter wheat) and disease severity (Table 4). Correlation analysis demonstrated a weak correlation between take-all incidence and cultivation area. However, take-all incidence and severity did not correlate with the amounts of G. graminis var. tritici/avenae DNA.

Table 4. Pearson correlation coefficients

\begin{tabular}{lcc}
\hline \multirow{2}{*}{ Variable } & \multicolumn{2}{c}{ Correlation coefficient } \\
\cline { 2 - 3 } & cultivation area & G. graminis var. tritici/avenae DNA \\
\hline Gaeumannomyces graminis var. tritici/avenae DNA & $0.566^{*}$ & - \\
Take-all index (TAI) & $0.565^{*}$ & 0.190 \\
Take-all incidence & 0.473 & 0.175 \\
\hline
\end{tabular}

\footnotetext{
* - significance of correlation coefficients at the $<0.05$
} 


\section{Discussion}

Different growing technologies, including reduced soil tillage and continuous wheat sowing, have become more popular in recent years (Bankina et al., 2015). Most often farmers do not necessarily use rotation and repeatedly grow wheat in the same field for at least 2-3 years, which strongly affects the amount of Ggt inoculum in the soil. Previous research on Ggt inoculum has focused on the possibility of infecting other crops, inoculum transfer in a break year, the survival of inoculum in field after harvesting and effects of environmental conditions and different length of break crops on Ggt inoculum in the soil (Gutteridge, Hornby, 2003; Gutteridge et al., 2006; 2007; Bithell et al., 2009). Takeall control is complicated, because the disease occurs in patches; the severity of the disease can significantly differ in different parts of the same field. Also the progression of disease epidemics in winter wheat is significantly influenced by the number of interacting factors (Hornby et al., 1998; Freeman, Ward, 2004; Bailey et al., 2005; Ennaifar et al., 2007). In this study, the cropping histories of inspected fields were not known, and it is likely that growing technologies, environmental and weather conditions differed between field sites. Therefore, the results in this paper show the overall prevalence of takeall in Lithuania.

Previous research has shown that high soil moisture levels are related to higher severity of take-all (Cook, 2003; Pillinger et al., 2005; Smiley, 2009). Cook (1981) indicated that for take-all to spread it needs a field with high water potential largely for the pathogens to grow and infect the plants in the $25 \mathrm{~cm}$ layer of the soil. The findings of this research indicated that the highest take-all severity was in the Middle Lowland zone and the lowest in the Western zone. Surprisingly, our findings slightly contradict the main aspects of the epidemiology of the disease. According to the mean annual amount of precipitation in our country (http://old.meteo.lt/ english/climate_precipitation.php), the greatest amount of precipitation falls annually in the Western zone and the lowest in the Middle Lowland. In Lithuania, the largest production areas of winter wheat with the highest productivity are concentrated in the Middle Lowland zone (Statistics Department of Lithuania, https://osp.stat. gov.lt/statistiniu-rodikliu-analize\#/), and it is normal that this important risk factor caused stronger development of the disease in this zone.

Soil type is a great risk factor; on lighter and low-mineral soils take-all can be very severe in wet seasons (Hornby et al., 1998). The most fertile soils in our country are in the Middle Lowland zone, and the least fertile soils are in the sandy Eastern zone (Motuzas et al., 2009) (Fig. 1). The study involving 81 fields showed differences of take-all incidence and severity between agro-ecological zones. The highest disease incidence and severity were in the Middle Lowland zone with most fertile soils and the largest production areas of winter wheat in Lithuania, while the lowest in Western zone of our country. Our study showed that the application of intensive growing technologies with continuous wheat sowing and rotations with limited break crops, which are often at greater risk of the disease damage, resulted in higher disease occurrence in the Middle Lowland zone.

Sowing date, tillage type and sequences of the rotations are important risk factors that influence the amounts of take-all and rates of epidemic development. The mentioned factors differed between the sites and were responsible for a strong variation in take-all severity in Lithuania. Series of studies showed negative influence of early sowing on the increase in take-all severity, especially when early sowing prevails in monocultures (Jenkyn et al., 1992). Research has proven that winter wheat sown with a delay left less inoculum of Ggt in the soil than sown early, because conditions for infection were less favourable and less inoculum of pathogens survived to infect plants (Hornby et al., 1998).

Tillage type influences the spatial structure of the diseases and might have an effect on prevalence of take-all. Ploughing can bury the infected residues, whilst tillage breaks up the infected plant residues which are more quickly degraded by other soil microorganisms (Wilkinston et al., 1985). Gosme et al. (2007) also have found a significant effect of soil management. Studies have shown higher take-all level in the plots with conservation tillage than in ploughed ones. Because the pathogens do not survive well in the soils without their hosts, it is very important to carefully plan crop rotation, which is one of the economically viable cultural take-all control methods (Cook, 2003; Jenkyn et al., 2014). Take-all severity is generally lower in wheat crops grown after non-host break crops. In the study conducted in Lithuania the take-all incidence and index clearly varied depending on the rotations. Out of the three winter wheat rotations, the lowest take-all incidence and severity were identified in the crop rotation, where winter wheat had been sown after oil seed rape, compared to winter wheat monoculture and second winter wheat (Ramanauskienè et al., 2018).

The amount of Ggt inoculum in the soil at the time of sowing greatly influences the primary infection of take-all in winter wheat. Primarily this is determined by the cropping history, the level of the disease in previous crop and inoculum decay time (Hornby et al., 1998). As expected, the Ggt/Gga inoculum level in the soil varied between the locations. The correlation analysis demonstrated that winter wheat cultivation area had influence on take-all severity and inoculum level in the soil. Because in this study the cropping histories of the inspected fields were not known, it is difficult to account for the main reasons for these differences. Therefore, the results in this paper show the overall amount of $G g t / G g a$ inoculum level in Lithuania.

\section{Conclusions}

1. Different site factors, also unpredictability of the disease (ability to spread in patches) are likely to be responsible for the marked variation of take-all prevalence in winter wheat crops. The presence of the disease was identified in $95.0 \%$ of the 81 winter wheat fields inspected. Depending on the site, the disease incidence varied from $2.0 \%$ to $92.0 \%$.

2. The highest take-all prevalence was detected in the Middle Lowland zone of Lithuania, where the largest production areas of winter wheat are concentrated.

3. A Pearson's correlation test showed very weak relationships between the take-all inoculum level in the soil and the disease severity. The lowest take-all index (TAI) but the highest amounts of Gaeumannomyces graminis var. tritici plus avenae (Ggt/Gga) DNA were established in the Western zone. 


\section{Acknowledgements}

The paper presents research findings, obtained through the long-term research programme "Harmful organisms in agro and forest ecosystems" (KOMAS) implemented by Lithuanian Research Centre for Agriculture and Forestry.

Received 26022018

Accepted 03012019

\section{References}

1. Bailey D. J., Gilligan C. A. 1999. Dynamics of primary and secondary infection in take-all epidemics. Phytopathology, 89: 84-91.

https://doi.org/10.1094/PHYTO.1999.89.1.84

2. Bailey D. J., Paveley N., Pillinger C., Foulkes J., Spink J., Gilligan C. A. 2005. Epidemiology and chemical control of take-all on seminal and adventitious roots of wheat Phytopathology, 95: 65-68. https://doi.org/10.1094/PHYTO-95-0062

3. Bailey D. J., Paveley N., Spink J., Lucas P., Gilligan C. A. 2009. Epidemiological analysis of take-all decline in winter wheat. Phytopathology, 99: 861-868. https://doi.org/10.1094/PHYTO-99-7-0861

4. Bankina B., Ruža A., Paura L., Priekule I. 2015. The effects of soil tillage and crop protection on the development of winter wheat leaf diseases. Zemdirbyste-Agriculture, 102 (1): 67-72. https://doi.org/10.13080/z-a.2015.102.008

5. Bithell S. L., Mclachlan A. R. G., Hide C. C. 1., Mckay A., Cromey M. G. 2009. Changes of post-harvest levels of Gaeumannomyces graminis var. tritici inoculum in wheat fields. Australasian Plant Pathology, 38: 277-283. https://doi.org/10.1071/AP09003

6. Bithell S. L., Mckay A., Butler R. C., Ophel-Keller K., Ophel-Keller H., Hartley D., Cromey M. G. 2012. Predicting take-all severity in second-year wheat using soil DNA concentrations of Gaeumannomyces graminis var. tritici determined with qPCR. Plant Disease, 96: 443-451. https://doi.org/10.1094/PDIS-05-11-0445

7. Bockus W. W., Tisserat N. A. 2000. Take-all root rot. The Plant Health Instructor.

https://doi.org/10.1094/PHI-I-2000-1020-01

8. Cook J. R. 1981. The effect of soil reaction and physical conditions. Asher M. J. C., Shipton P. J. (eds). Biology and control of take-all. Academic Press, p. 343-352.

9. Cook J. R. 2003. Take-all of wheat. Review. Physiological and Molecular Plant Pathology, 62: 73-86. https://doi.org/10.1016/S0885-5765(03)00042-0

10. Cook J. R. 2007. Take-all decline: model system in the science of biological control and clue to the success of intensive cropping. Vincent C. et al. (eds). Biological control: a global perspective. $\mathrm{CAB}$ International, chapter 44 , p. 399-414. https://doi.org/10.1079/9781845932657.0399

11. Cromey M. G., Parkes R. A., Fraser P. M. 2006. Factors associated with stem base and root diseases of New Zealand wheat and barley crops. Australasian Plant Pathology, 35: $1-10$. https://doi.org/10.1071/AP06032

12. Curtin D., Francis G. S., McCallum F. M. 2008. Decomposition rate of cereal straw as affected by soil placement. Australasian Journal of Soil Research, 46: $152-160$ https://doi.org/10.1071/SR07085

13. Ennaifar S., Makowski D., Meynard J. N., Lucas P. 2007. Evaluation of models to predict take-all incidence in winter wheat as a function of cropping practices, soil and climate. European Journal of Plant Pathology, 118: 127-143. https://doi.org/10.1007/s10658-007-9119-7
14. Freeman J., Ward E. 2004. Gaeumannomyces graminis, the take-all fungus and its relatives. Molecular Plant Pathology, 5: 235-252.

https://doi.org/10.1111/j.1364-3703.2004.00226.x

15. Gosme M., Willosquet L., Lucas P. 2007. Size, shape and intensity of aggregation of take-all disease during natural epidemics in second wheat crops. Plant Pathology, 56: 87-96. https://doi.org/10.1111/j.1365-3059.2006.01503.x

16. Gutteridge R. J., Hornby D. 2003. Effects of sowing data and volunteers on the infectivity of soil infested with Gaeumannomyces graminis var. tritici and on take-all disease in successive crops of winter wheat. Annals of Applied Biology, 143: 272-282. https://doi.org/10.1111/j.1744-7348.2003.tb00295.x

17. Gutteridge R. J., Bateman G. L., Todd A. D. 2003. Variation in the effects of take-all disease on grain yield and quality of winter cereals in field experiments. Pest Management Sciences, 59: 215-224. https://doi.org/10.1002/ps.574

18. Gutteridge R. J., Jenkyn J. F., Bateman G. L. 2006. Effects of different cultivated or weed grasses, grown as pure stands or in combination with wheat, on take-all and its suppression in subsequent wheat crops. Plant Pathology, 55: 696-704. https://doi.org/10.1111/j.1365-3059.2006.01405.x

19. Gutteridge R. J., Jenkyn J. F., Bateman G. L. 2007. The potential of non-pathogenic Gaeumannomyces spp., occurring naturally or introduced into wheat crops or preceding crops, for controlling take-all in wheat. Annals of Applied Biology, 150: 53-64. https://doi.org/10.1111/j.1744-7348.2006.00107.x

20. Hornby D., Bateman G. L., Guitteridge R. J., Lucas P., Osbourn A. E., Ward E., Yarham D. J. 1998. Take-all disease of cereals: a regional perspective. CAB International, $384 \mathrm{p}$.

21. Jenkyn J. F., Gutteridge R. J., Todd A. D. 1992. Effects of sowing winter barley on different dates in autumn on the severity of take-all (Gaeumannomyces graminis var. tritici) in those and the subsequent crops. Journal of Agricultural Science, 119: 19-25. https://doi.org/10.1017/S0021859600071501

22. Jenkyn J. F., Gutteridge R. J., White R. P. 2014. Effects of break crops, and of wheat volunteers growing in break crops or in set-aside or conservation covers, all following crops of winter wheat, on the development of take-all (Gaeumannomyces graminis var. tritici) in succeeding crops of winter wheat. Annals of Applied Biology, 165: 340-363. https://doi.org/10.1111/aab.12139

23. Kwak Y.-S., Weller D. M. 2013. Take-all of wheat and natural disease suppression: a review. The Plant Pathology Journal, 29: 125-135. https://doi.org/10.5423/PPJ.SI.07.2012.0112

24. Liu X., Yang L., Zhou X., Zhou M., Lu Y., Ma L., Ma H., Zhang Z. 2013. Transgenic wheat expressing Thinopyrum intermedium MYB transcription factor TiMYB2R-1 shows enhanced resistance to the take-all disease. Journal of Experimental Botany, 64: 2243-2253. https://doi.org/10.1093/jxb/ert084

25. McMillan V. E., Hammond-Kosack K. E., Guiteridge R. J. 2011. Evidence that wheat cultivars differ in their ability to build up inoculum of the take-all fungus Gaeumannomyces graminis var. tritici, under a first wheat crop. Plant Pathology, 60: 200-206. https://doi.org/10.1111/j.1365-3059.2010.02375.x

26. Motuzas A. J., Buivydaitè V. V., Vaisvalavičius R., Šleinys R. A. 2009. Dirvotyra, 286-290 p. (in Lithuanian).

27. Nicolaisen M., Supronienė S., Nielsen L. K., Lazzaro I., Spliid N. H., Justesen A. F. 2009. Real-time PCR for quantification of individual Fusarium species in cereals. Journal of Microbiological Methods, 76 (3): 234-240. https://doi.org/10.1016/j.mimet.2008.10.016 
28. Pillinger C., Paveley N., Foulkes M. J., Spink J. 2005. Explaining variation in the effects of take-all (Gaeumannomycesgraminis var. tritici) on nitrogen and water uptake by winter wheat. Plant Pathology, 54: 491-501. https://doi.org/10.1111/j.1365-3059.2005.01229.x

29. Ramanauskienė J., Semaškienė R., Jonavičienè A., Ronis A. 2018. The effect of crop rotation and fungicide seed treatment on take-all in winter cereals in Lithuania. Crop Protection, 110: 14-20. https://doi.org/10.1016/j.cropro.2018.03.011

30. Shoeny A., Jeuffroy M. H., Lucas P. 2001. Influence of take-all epidemics on winter wheat yield formation and yield loss. Phytopathology, 91: 694-701. https://doi.org/10.1094/PHYTO.2001.91.7.694

31. Smiley R. W. 2009. Water and temperature parameters associated with winter wheat diseases caused by soilborne pathogens. Plant Pathology, 93: 73-80.

32. Walker J. L. 1981. Taxonomy of the take-all fungi and related genera and species. Asher M. J. C., Shipton P. J. (eds). Biology of take-all. Academic Press, p. 15-74.

33. Weller D. M., Raaijmakers J. M., Gardener B. B. M., Thomashow L. S. 2002. Microbial populations responsible for specific soil suppressiveness to plant pathogens. Annual Review of Phytopathology, 40: 309-348.

https://doi.org/10.1146/annurev.phyto.40.030402.110010
34. Werker A. R., Gilligan C. A. 1990. Analysis of the effects of selected agronomic factors on the dynamics of the take-all disease of wheat in field plots. Plant Pathology, 39: 161-177. https://doi.org/10.1111/j.1365-3059.1990.tb02487.x

35. Wilkinston H. T., Cook R. J., Alldredge J. R. 1985. Relation of inoculum size and concentration to infection of wheat roots by Gaeumannomyces graminis var. tritici. Phytopathology, 75: 98-103. https://doi.org/10.1094/Phyto-75-98

36. Witzenberger A., Hack H., Van den Boom T. 1989. Erläuterungen zum BBCH-Dezimal-Code für die Entwicklungsstadien des Getreides - mit Abbildungen. Gesunde Pflanzen, 41: 384-388 (in German).

37. Yang M., Mavrodi D. V., Mavrodi O. V., Bonsall R. F., Parejko J. A., Paulitz T. C., Thomashow L. S., Yang H. T., Welle D. M., Guo J. H. 2011. Biological control of takeall by fluorescent Pseudomonas spp. from Chinese wheat fields. Phytopathology, 101: 1481-1491. https://doi.org/10.1094/PHYTO-04-11-0096

ISSN 1392-3196 / e-ISSN 2335-8947

Zemdirbyste-Agriculture, vol. 106, No. 1 (2019), p. 37-44

DOI 10.13080/z-a.2019.106.005

\title{
Javaklupès išplitimas bei intensyvumas žieminiuose kviečiuose ir Gaeumannomyces graminis infekcijos lygis Lietuvos dirvožemiuose
}

\author{
J. Ramanauskienė, Z. Dabkevičius, K. Tamošiūnas, E. Petraitienė \\ Lietuvos agrarinių ir miškų mokslų centro Žemdirbystės institutas
}

\section{Santrauka}

Pastaraisiais metais dèl nuolat kintančių žemdirbystès sistemų taikymo ir riboto alternatyvių kultūrų pasirinkimo daugelis ūkininkų tuos pačius augalus tame pačiame lauke dažnai augina dvejus ar daugiau metų iš eilès. Tai turi didelę įtaką javaklupès plitimo rizikai žieminių kviečių pasėliuose. Tyrimo tikslas - ịvertinti javaklupès išplitimą ir intensyvumą žieminių kviečių pasėliuose ir nustatyti ligos sukėlèjų Gaeumannomyces graminis var. tritici (Ggt) ir G. graminis var. avenae ( $\mathrm{Gga}$ ) infekcijos lygị skirtingų Lietuvos agroekologinių zonų dirvožemiuose. Tyrimo laikotarpiu buvo ištirta 81 žieminių kviečių pasèlis. Priklausomai nuo tyrimo metų ir vietovès, javaklupès išplitimas pasėliuose ịvairavo nuo 2,0 iki 92,0 \%. Tyrimo duomenimis, javaklupé žieminius kviečius smarkiausiai pažeidė Vidurio žemumos zonoje, o ligos mažiausias intensyvumas nustatytas Vakarų zonoje. Ggt/Gga infekcijos lygis dirvožemyje buvo nustatytas taikant jauko metodą ir įvertinus patogenų DNR kiekį žieminių kviečių šaknelèse, išaugintose skirtingų Lietuvos agroekologinių zonų dirvožemių mėginiuose. Ggt/Gga DNR kiekis smarkiai varijavo tarp vietovių. Vidutiniais duomenimis, mažesnis javaklupės infekcijos lygis nustatytas Rytų zonoje, didesnis Vidurio žemumos zonoje. Didžiausi Ggt/Gga DNR kiekiai nustatyti Pakruojo ir Panevėžio rajonuose. Trijuose dirvožemio mėginiuose, kurie buvo paimti Raseinių, Šiaulių ir Alytaus rajonuose, nustatyti labai maži kiekiai (tik 0,188-0,640 pg grybo DNR $\mu \mathrm{g}^{-1}$ augalo DNR) patogenų DNR, o penkiuose tirtuose dirvožemio mėginiuose iš Šilutès, Tauragès, Telšių, Kẻdainių ir Panevėžio rajonų Ggt/Gga DNR neaptikta. Nustatyta kad, skirtingų javų auginimo technologijų taikymas ir nevienodos šalies oro bei aplinkos sąlygos, taip pat ligos gebejimas plisti židiniais, sunkinantis javaklupės kontrolę, tikètina, buvo pagrindinė priežastis, kuri turèjo esminès įtakos smarkiam javaklupès išplitimo ir intensyvumo varijavimui žieminių kviečių pasèliuose.

Reikšminiai žodžiai: grybo infekcija, javaklupès intensyvumo indeksas, kiekybinis įvertinimas, Triticum aestivum. 